\title{
Role of Adrenomedullin in Patients with Rheumatoid Arthritis
}

\author{
Etsuo Chosa, Hiroaki Hamada and Toshiyuki Ohkura \\ Division of Orthopaedic Surgery, Department of Medicine of Sensory and \\ Mortor Organs, Faculty of Medicine, University of Miyazaki
}

Japan

\section{Introduction}

The mechanism of arthritis including rheumatoid arthritis (RA) has not been clarified enough in terms of its molecular biology. However, owing to advances in techniques to produce monoclonal antibodies and genetic engineering techniques to produce recombinant proteins, targeted therapies have progressed. Tumor necrosis factor-alpha (TNF- $\alpha$ ), interleukin-1 (IL-1), interleukin-6 (IL-6), and T-cells (CD28) are representative targets, and therapies targeting them have produced epoch-making results in the treatment of RA. In this text, we report the role and effects of therapy with adrenomedullin as a novel, promising targeted therapy.

Adrenomedullin (ADM) is a peptide that was discovered by the assay-based monitoring of platelet CAMP activity (Kitamura et al., 1993). This protein shows not only marked vasodilatory but also in vivo and in vitro anti-inflammatory activities (Isumi et al., 1998).

To determine the efficacy of ADM in patients with RA, we researched the plasma level of $\mathrm{ADM}$ and its correlation with the plasma CRP level. The result showed that the plasma ADM level in patients with RA was twice that in healthy controls and strongly correlated with the blood CRP level, and the ADM level in synovial tissue in patients with RA was 3 times that in patients with osteoarthritis (Chosa et al., 2003). Then, thorough research is needed to examine whether the cultured RA synoviocytes are related to the ADM in vitro. The result showed that ADM was produced from RA synoviocytes and reduced the IL-6 level in cultured media (Fig. 5). These results suggest the close involvement of ADM in arthritis in RA. Therefore, to examine the therapeutic efficacy of intra-articular ADM injection, we injected ADM into the joint of a rabbit model of adjuvant arthritis, and confirmed the inhibition of arthritis at an early stage. These findings suggest the potentiality of ADM as a novel drug for the treatment of arthritis in RA (Okura et al., 2008).

\section{Measured adrenomedullin (ADM) in patients with RA}

\subsection{Patient background}

For measurement of plasma ADM, the study population consisted of 26 patients with RA aged 58-73 years (mean \pm SD $62 \pm 4$ yrs), 10 with osteoarthritis (OA) aged 59-76 years 
$(68 \pm 8)$, and 10 healthy volunteer controls aged 50-66 years $(57 \pm 5)$. All subjects were female.

To clarify further the reason for the increase in plasma ADM, joint fluid, synovial tissue, and cartilage were measured by radioimmunoassay (RIA). These were acquired from surgical subjects during total knee arthroplasty in patients with RA $(n=6)$ and OA $(n=6)$. All patients with RA were classified as stage 4, functional class 2, according to the criteria of the American Rheumatism Association (ARA) (Clegg \& Ward, 1987); they were medicated with only DMARDs and NSAIDs without steroid. All patients with OA were classified as stage 4 to 5, according to the Kellgren-Lawrence radiographic staging system (Kellgren \& Lawrence, 1958). Since plasma ADM concentration has been reported to be elevated in patients with hypertension, renal failure, systemic infections, myocardial infarction, and heart failure (Ishimitsu et al., 1994; Nishikimi et al., 1995; Kobayashi et al., 1996), patients and controls with these conditions were excluded.

\subsection{Methods of measuring ADM levels in plasma, joint fluid and joint tissues 2.2.1 Methods measuring the plasma and joint fluid ADM level}

Blood and joint fluid samples were transferred into tubes containing $1 \mathrm{mg} / \mathrm{ml}$ EDTA-2Na and 500 kallikrein inhibitory units/ml of aprotinin for measurement of ADM. The plasma was kept at $-30^{\circ} \mathrm{C}$ until assayed. Levels of plasma ADM and joint fluid ADM were measured by IRMA using specific kits (AM RIA Shionogi) developed by Shionogi Pharmaceutical Co. Ltd., Osaka, Japan. The limit of detection of human AM is $0.5 \mathrm{pmol} / 1$ for these kits.

\subsubsection{Extraction of ADM in joint tissues}

For measuring ADM levels of acquired joint fluids, samples were acidified with acetic acid to a final concentration of $1.0 \mathrm{M}$ and centrifuged at $3000 \mathrm{rpm}$ for $5 \mathrm{~min}$, while synovium and cartilage specimens were acidified with acetic acid to a final concentration of $1.0 \mathrm{M}$ and boiled for $10 \mathrm{~min}$ to inactivate proteases. The samples were then homogenized and centrifuged for $90 \mathrm{~min}$ at 12,000 rpm. The supernatant of samples was applied to a Sep-Pak C18 cartridge (Millipore-Waters, Milford, MA, USA). After the cartridge was washed with $10 \% \mathrm{CH}_{3} \mathrm{CN}$ in $0.1 \%$ trifluoroacetic acid, the absorbed materials were eluted with $50 \%$ $\mathrm{CH}_{3} \mathrm{CN}$ in $0.1 \%$ trifluoroacetic acid. The eluted samples were dried by speed vacuum, freeze-dried and stored at $-30^{\circ} \mathrm{C}$ until assayed.

\subsubsection{Radioimmunoassay for ADM}

The RIA for ADM was performed as described previously (Kitamura et al., 1994). The incubation buffer for RIA was $0.05 \mathrm{M}$ sodium phosphate buffer $(\mathrm{pH} 7.4)$, containing $0.5 \%$ BSA, $0.5 \%$ Triton X-100, $0.08 \mathrm{M} \mathrm{NaCl}, 0.025 \mathrm{M}$ EDTA $2 \mathrm{Na}, 0.05 \% \mathrm{NaN}_{3}$, and $500 \mathrm{KIU} / \mathrm{ml}$ trasylol. A disposable plastic tube $(10 \times 75 \mathrm{~mm})$ was used for assaying. All assay procedures were performed at $4^{\circ} \mathrm{C}$. Both standard ADM and unknown samples $(100 \mu \mathrm{l})$ were incubated with anti-ADM antiserum diluent $(200 \mu \mathrm{l})$ for $12 \mathrm{~h}$ before the tracer solution (125I-AM, $18,000-20,000$ counts/min in $100 \mu \mathrm{l}$ ) was added. After incubation for $16 \mathrm{~h}$, anti-rabbit IgG goat serum diluent $(100 \mu \mathrm{l})$ was added. After standing for $24 \mathrm{~h}$, the tubes were centrifuged at $3000 \mathrm{rpm}$ for $30 \mathrm{~min}$ at $4^{\circ} \mathrm{C}$ and the radioactivity of the precipitate was measured using an Aloka ARC-600 gamma counter. 


\subsection{Result of ADM in plasma, joint fluid and joint tissues in patients with RA Discussion of joint ADM level in patients with RA}

It has been reported that some collagenous disorders show increased levels of plasma ADM (Yudoh et al., 1999). We measured and compared plasma ADM concentrations in patients with RA and healthy controls, finding that patients with RA exhibited a 1.7-fold increase in plasma ADM levels (Table 1).

\begin{tabular}{lcc}
\hline & Tolal ADM (fmol / ml) & Mature ADM (fmol / ml) \\
\hline Healthy controls & $11.64 \pm 2.8$ & $1.34 \pm 0.9$ \\
RA patients & $18.35 \pm 6.9$ & $1.80 \pm 1.4$ \\
OA patients & $12.88 \pm 1.9$ & $1.42 \pm 0.8$ \\
\hline
\end{tabular}

Table 1. Blood adrenomedullin (ADM) levels in RA and OA patients and healthy controls

All values are expressed as means \pm SD. $\% p<0.01$. Patients with RA demonstrated high plasma concentration of ADM $(18.35 \pm 6.9 \mathrm{fmol} / \mathrm{ml})$ compared to healthy controls $(11.64 \pm$ $2.8 \mathrm{fmol} / \mathrm{ml})$ and $\mathrm{OA}$ patients $(12.88 \pm 1.9 \mathrm{fmol} / \mathrm{ml})$

Moreover, plasma ADM levels in patients with RA were also found to be significantly correlated to CRP levels (Fig. 1). In RA, CRP correlates with disease activity and response to therapy. Our patient data did not include RA disease activity, excluding RA functional class classification. Hamada et al. (2010) stated that no autologous antibody such as rheumatoid factor or anti-CCP antibody showed significant correlation with plasma ADM level. In addition, there was no correlation with disease activity scores such as DAS-28. DAS-28 is not only dependent on the inflammatory level, so the plasma ADM level may escalate before escalation of the activity in synovitis or the amount of actual synovial inflammation (Hamada et al., 2010). Therefore, our results suggest that ADM levels are increased in patients with RA and investigated that they might be correlated with disease activity. Moreover, ADM concentration in the joint fluid of RA patients $(10.8 \pm 4.3 \mathrm{fmol} / \mathrm{ml})$ was significantly higher than that of OA patients $(7.2 \pm 1.8 \mathrm{fmol} / \mathrm{ml})$ (Fig. 2).

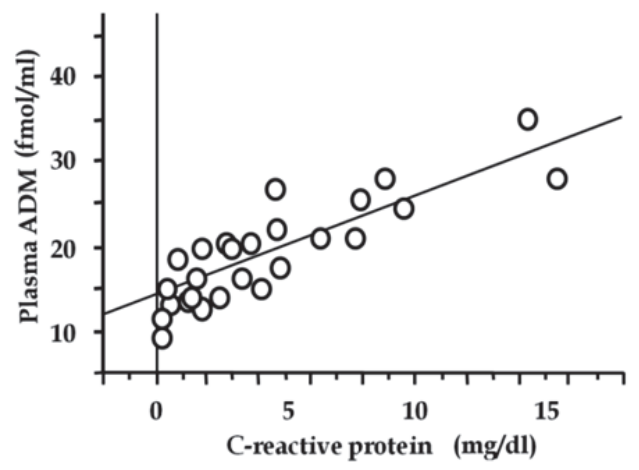

Fig. 1. Correlation between plasma AM and C-reactive protein

A significant positive correlation was observed between AM and CRP (correlation coefficient $=0.685, \mathrm{p}<0.01$ ). Plasma ADM and plasma CRP levels were found to be well correlated. The correlation coefficient between CRP and AM was 0.685, p $<0.01$. 


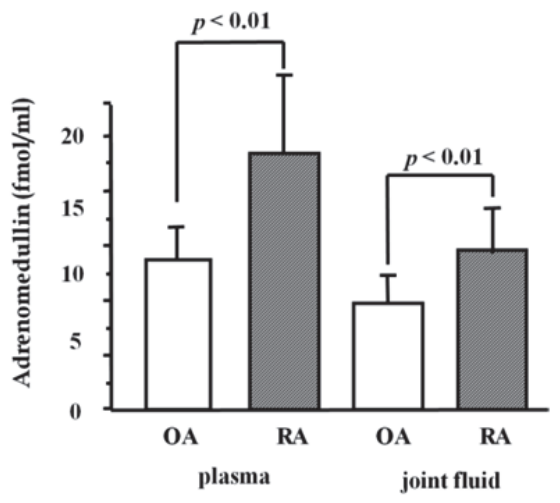

Fig. 2. Concentration of ADM between RA and OA in plasma and joint fluid

Patients with RA demonstrated high plasma concentration of ADM $(18.35 \pm 6.9 \mathrm{fmol} / \mathrm{ml})$ compared to OA patients $(12.88 \pm 1.9 \mathrm{fmol} / \mathrm{ml})$. ADM concentration in the joint fluid of RA patients $(10.8 \pm 4.3 \mathrm{fmol} / \mathrm{ml})$ was significantly higher than that of OA patients $(7.2 \pm 1.8$ $\mathrm{fmol} / \mathrm{ml})$

We applied conventional radioimmunoassay (RIA) to determine ADM concentration in tissues. RA is characterized by the presence of inflammatory synovitis accompanied by destruction of joint cartilage and bone. The concentration of ADM in the synovium of RA patients was 3.2-fold higher than that of OA patients (Fig. 3). In addition, the concentration of ADM in plasma of RA patients was 1.4-fold higher than that of OA patients (Table 2). To determine the relationship between plasma ADM and arthritis in patients with RA, we compared ADM levels in joint fluid of RA and OA patients. Joint fluid is similar in composition to plasma, which explains the similarly significant increases in ADM concentration in both plasma and joint fluid in patients with RA compared with those with OA $(p<0.01)$ (Fig. 2). These observations indicate that the reason for this high concentration of ADM might be secretion from synovial stromal cells or secretion from synovial vascular wall cells. However, the mechanism by which plasma and joint fluid ADM levels increase in patients with RA remains unknown.

Several tissues including vessels secrete ADM, and elevated ADM could conceivably be caused by secretion from vascular cells in general. When we consider the results, in which ADM levels in the synovium of RA patients were higher than those of OA patients, we may assume that synovitis is one reason for the increased ADM concentration in synovium and joint fluid, and may partially contribute to the increase in ADM levels in plasma. Our results indicate the possibility that ADM participates in the pathophysiology of joint lesions in patients with RA. Together with the fact that ADM is known to inhibit the secretion of cytokines from several cell lines (Isumi et al., 1999; Kamoi et al., 1995), the findings seem to validate the assumption that production and secretion of ADM in synovium are strongly correlated with anti-inflammation in arthritis. Thus, the elevation of plasma ADM levels may be related to the anti-inflammatory response. Clementi et al. (1999) investigated the anti-inflammatory effect of ADM in rats, finding that ADM production in several cell lines was strongly induced by stimulation of a group of inflammatory cytokines including interleukin 1 and tumor necrosis factor-a (TNF-a) (Hofbauer et al., 2002). Some studies report that $\mathrm{ADM}$ acts as a circulating vasoactive hormone in blood, and plays an antiinflammatory role in the prevention of local infection and inflammation, thus contributing 
to host defense systems (Ueda et al., 1999; Elsasser \& Kahl, 2002). From these observations, we speculate that ADM may play a role in the pathophysiology of inflammation as well as in the regulation of joint disorders.

Synovitis inevitably plays a role in the destruction of joint surface, so we measured the concentration of ADM in articular cartilage. We found the ADM concentration in cartilage was lower than that of other tissues (Fig. 2). While the concentration of ADM in normal human articular cartilage has not been determined, an immunohistochemical study has reported that normal human articular chondrocytes produce ADM (Fig. 4) (Asada et al., 1999). No statistically significant difference was found in the articular cartilage concentration of ADM in RA and OA patients (Fig. 3). We therefore speculate that this may be because our samples were from cases that consisted of end-stage arthritis, with advanced degeneration and differentiation of the cartilage. A thorough investigation of the role of ADM in cartilage pathophysiology is necessary.

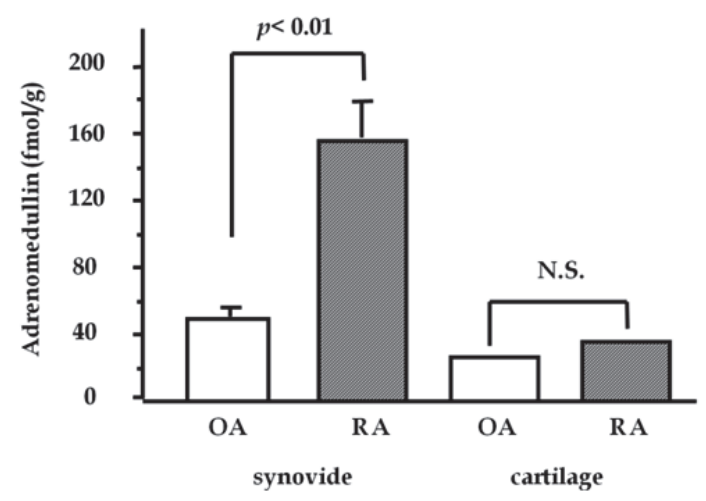

Fig. 3. Concentration of ADM for synovium and articular cartilage in patients with OA and RA RA patients showed higher concentrations of ADM in synovium compared to OA patients. ${ }^{*} \mathrm{p}<0.01$; ${ }^{* *}$ not significant. In cartilage, there is no significantly difference between the concentration of OA and RA

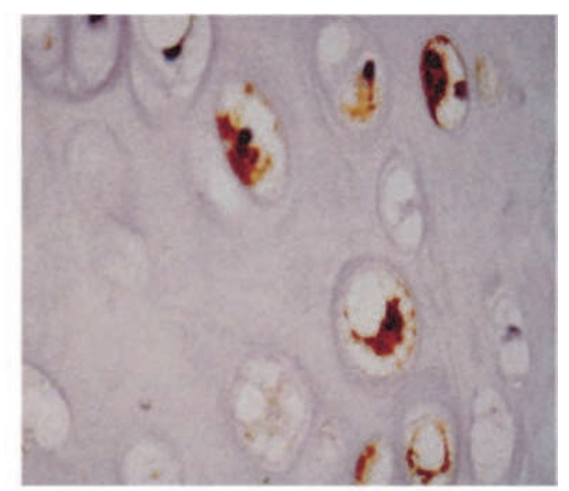

Fig. 4. Novel distribution of adrenomedullin-immunoreactive cells in human cartilage

Hyaline cartilage: Chondrocytes are positive for ADM. (donated from Prof. Asada, Miyazaki University) 
We observed that plasma ADM concentration in patients with RA was higher than that of healthy controls, and plasma ADM and plasma CRP levels were found to be well correlated. Our data suggest that plasma ADM levels increase with the activity of RA. We conclude that ADM probably plays a part in the regulation of the inflammatory process of RA, and its plasma and/or joint fluid levels could be used as an index of the degree of RA. Therefore, we investigated the role of ADM in inflammation in cultured RA synoviocytes (fibroblastlike synovium) in a subsequent investigation.

\section{Effiency of ADM in cultured synovia (fibroblast-like synoviocytes)}

\subsection{Methods of ADM study in cultured FLS}

\subsubsection{Fibroblast-like synoviocytes (FLS) culture}

Synovial tissue specimens were collected under sterile conditions from 6 patients with RA. Specimen collection occurred during total knee arthroplasty in all patients with RA. All RA patients fulfilled 1987 American College of Rheumatology criteria for RA. All of them were treated with only NSAIDs, DMARDs and hyaluronic acid injection into the joint before samples were obtained. The methods of FLS culture was described previously (Nanki, et al., 2001).

\subsubsection{Characterization of secreted ADM}

To examine the molecular forms of ADM, extracts of cells cultured on a $100-\mathrm{mm}$ dish and 15 $\mathrm{ml}$ of the conditioned medium (1\%FBS) were analyzed by reverse-phase high-performance liquid chromatography (HPLC) with a column of TSK ODS 120 A (Tosoh, Tokyo, Japan). A linear gradient of $10 \%$ to $60 \%$ acetonitrile was run in $0.1 \%$ trifluoroacetic acid for 60 minutes and the ir-AM level in each fraction was measured by RIA. The recovery of ir-ADM from this HPLC system was greater than $80 \%$.

\subsection{IL-6 secretion was inhibited in cultured FLS after addition of ADM}

The present study demonstrated that cultured RA synoviocytes expressed the mRNA for ADM and also actively secreted ADM (Fig. 5). The active secretion of ADM by RA synoviocytes seems to be similar to its active secretion by endothelial cells (Hojo et al., 2001; Uemura et al., 2002). ADM in the culture medium seemed to be actual AM because reversephase HPLC revealed that most of the ADM secreted into the medium emerged at the

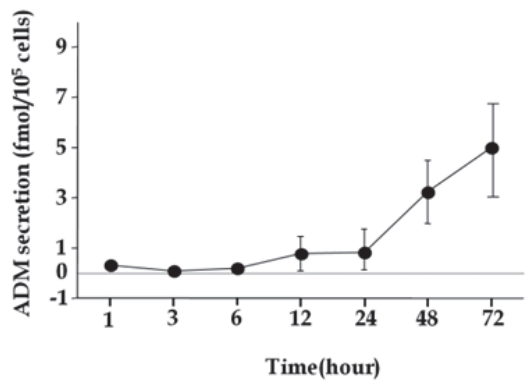

Fig. 5. Time course curve for secretion of AM and intracellular ADM

The cells were incubated for the indicated time-periods in serum free medium, and the ADM was determined by RIA. Intracellular ADM was too low to be determined. 
identical elution position to that of authentic human ADM (1-52), which is the full-length human ADM peptide (Fig. 6). The minor peak that was eluted earlier was thought to be oxidized ADM containing methione sulfoxide. The intracellular ADM concentration remained extremely low in RA synoviocytes (Fig. 5), suggesting that these cells constitutively secrete ADM. Thus, RA synoviocytes seem to secrete ADM rapidly after its synthesis, with little intracellular storage.

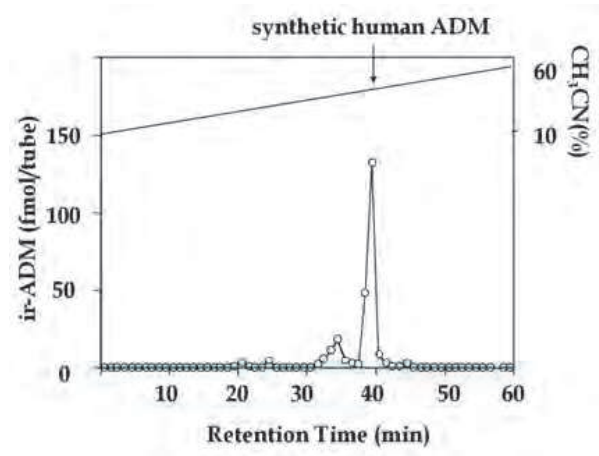

Fig. 6. Analysis by reverse-phase HPLC of immunoreactive adrenomedullin (ir-ADM) secreted into the media

A linear gradient of acetonitrile of $10 \%$ to $60 \%$ was made in $0.1 \%$ trifluoroacetic acid for 60 minutes at a flow rate of $1.0 \mathrm{~mL} / \mathrm{min}$. The arrow indicates the elution position of synthetic human AM. The specificity of the RIA was clarified.

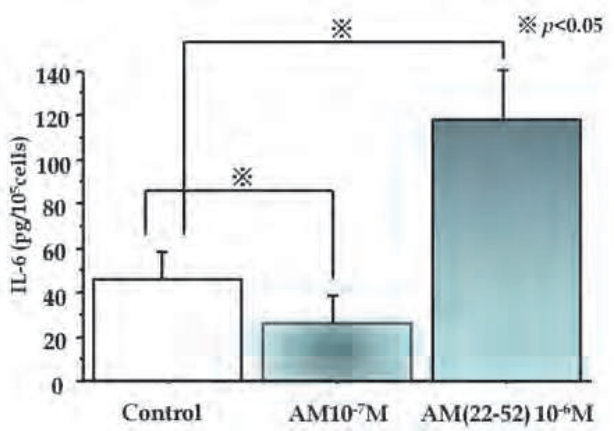

Fig. 7. Inhibitory effect of ADM about the IL-6 secretion into the media in cultured FLS

Effects of ADM 22-52 10-6M (ADM blocker) on control level of IL-6 secretion in cultured fibroblast like synoviocytes (FLS) donated from RA patients. Serum-starved FLS were incubated 24 hours. Values are the means \pm SEM of six wells examined. Each was compared with the cells incubated with 1\%FBS media (control). Each set of experiments was repeated three times and identical results were obtained.

When the synoviocytes reached confluence, $\operatorname{ADM}\left(10^{-8} \mathrm{M}\right)$ was added to the culture media. After 24 hours, the level of IL-6 in culture media significantly decreased. Moreover, ADM (22-52), which is an ADM antagonist, elevated the level of IL-6 in culture media (Fig. 7). 
These observations lead us to conclude that ADM inhibited the secretion of IL-6 and regulated the IL-6 production in the cultured RA synoviocytes.

Besides the findings in our study, a similar report stated that ADM reduced constitutive production of IL6 from RA synoviocytes in a dose-dependent manner. A high concentration of ADM (>10-8 mmol/l) significantly reduced constitutive production of IL6 compared with a low concentration of ADM ( $<10-9 \mathrm{mmol} / \mathrm{l})(\mathrm{p}=0.0029)$ (Nanke et al., 2003). Then, we tried to inject ADM into the knee in antigen-induced arthritis in rabbits.

\section{Adrenomedullin injection to the knee in antigen-induced arthritis (AIA) in rabbits}

\subsection{Methods}

\subsubsection{Induction of antigen-induced arthritis}

The AIA rabbit model was developed as described by Consden and colleagues (Consden et al., 1971). Briefly, rabbits were anesthetized by an intravenous injection of pentobarbital sodium and were immunized by $1.2 \mathrm{ml}$ intradermal injections of $6 \mathrm{mg} / \mathrm{ml}$ ovalbumin (Sigma-Aldrich, St Louis, MO, USA) in saline emulsified with an equal volume of TiterMax Gold (TiterMax, Norcross, GA, USA). The rabbits were re-immunized in the same manner 30 days later. Seven days after the second immunization, the rabbits underwent skin testing following a $0.1 \mathrm{ml}$ intradermal injection of a solution of $200 \mu \mathrm{g} / \mathrm{ml}$ ovalbumin in saline. Animals exhibiting a welt of $13 \mathrm{~mm}$ or greater after 24 hours were confirmed as 'immunized'. Twelve days after the second immunization, the 'immunized' rabbits were anesthetized and arthritis was induced by $0.5 \mathrm{ml}$ bilateral knee intra-articular injections of a solution of $20 \mathrm{mg} / \mathrm{ml}$ ovalbumin in saline.

\subsubsection{Treatment protocol}

Twenty-four hours after arthritis induction, the rabbits were anesthetized and different doses of ADM (1 ng to $3 \mu \mathrm{g}$; Peptide Institute Inc., Osaka, Japan) dissolved in $0.3 \mathrm{ml}$ saline were injected into the knee joint spaces or $0.3 \mathrm{ml}$ saline was injected into the contralateral knee joint spaces as controls. For time-course experiments, ADM and saline were injected into the knee joint spaces daily for 7 days and 20 days. The rabbits were sacrificed on day 8 ( $n=5$ in each group) and day 21 ( $n=3$ in each group).

\subsubsection{Joint swelling}

To evaluate the grade of arthritis/inflammation, joint swelling was assessed by measuring the maximum diameter of the swollen joint using calipers. The swelling was compared with that at the same level on the contralateral knee, treated with saline.

\subsubsection{Histological evaluation}

For histological evaluation, rabbits were given an overdose of pentobarbital 8 days and 21 days after arthritis induction. The infrapatellar fat pads were harvested from dissected knees and were cut longitudinally, perpendicular to the patella ligament in the middle of the infrapatellar fat pad. The tissues were fixed in $10 \%$ buffered formaldehyde and embedded in paraffin wax, and sections $3 \mu \mathrm{m}$ thick were obtained. The specimens were stained with $\mathrm{H} \& \mathrm{E}$ and Mallory-Azan stains. The area of the infrapatellar fat pad was measured using AxioVision software (release 4.3; ZEISS, Oberkochen, Germany). 
Inflammatory cells, including lymphocytes and plasma cells, were counted in the superficial and deep portions of the infrapatellar fat pads (three fields under $\times 200$ magnification in each portion) in $\mathrm{H} \&$ E-stained specimens. The inflammatory cell count was performed by two independent observers.

To measure the collagen volume, the images of sections with Mallory-Azan stain were projected onto a color imaging analysis system (Mac SCOPE version 2.3.2; Mitani, Fukui, Japan). In each section, 10 separate sites were analyzed at $\times 40$ magnification. The collagen volume fraction was obtained by calculating the mean ratio of connective tissue to the total tissue area.

\subsubsection{Measurement of cytokine mRNA}

Total RNA was extracted from the infrapatellar fat pad with TRIzol reagent (Invitrogen, Carlsbad, CA, USA) according to the manufacturer's protocol and was then reversetranscribed into cDNA with the SuperScript First-Strand Synthesis System for RT-PCR kit (Invitrogen). To measure rabbit TNFa, IL-6, vascular endothelial growth factor (VEGF), transforming growth factor beta (TGF $\beta$ ), and $\beta$-actin mRNA levels, we used the quantitative RT-PCR method of real-time quantitative PCR.

\subsection{Result after joint injection of ADM in AIA rabbit}

\subsubsection{Adrenomedullin concentration in plasma}

We measured the plasma ADM concentration before and 15, 30, 60 and 120 minutes after intra-articular injection of $3 \mu \mathrm{g} \operatorname{ADM}(n=6)$. No significant change, however, was observed in the plasma concentration of ADM (Figure (Figure1).1). The intra-articular injection of ADM did not therefore increase the level of ADM in plasma.

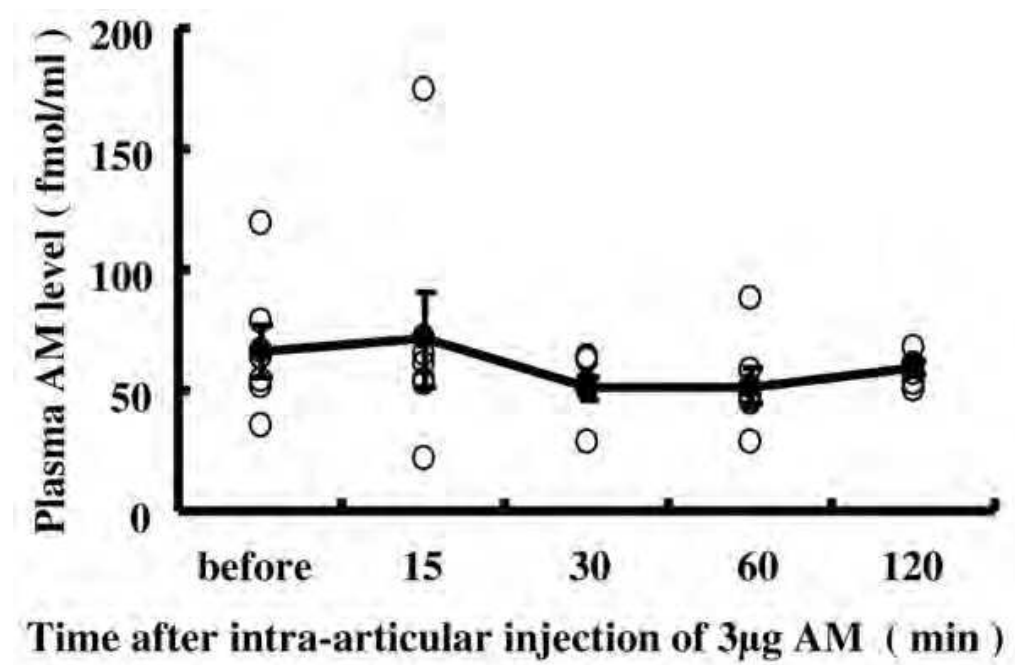

Fig. 8. Sequential concentrations of plasma ADM following intra-articular ADM injection in rabbits with antigen-induced arthritis.

Whole-blood samples (total $1 \mathrm{ml}$ ) were taken from a peripheral artery in the rabbit ear using a 22-gauge needle before and 15, 30,60 and 120 minutes after intra-articular injection of $3 \mu \mathrm{g}$ 
adrenomedullin (AM). The plasma AM concentration was measured using an immunoenzymometric assay kit $(n=6)$. White circles, plasma AM levels in rabbits; black circles, average plasma AM levels at each time point after intra-articular injection of $3 \mu \mathrm{g}$ AM. Data expressed as the mean \pm SEM. Each of plasma ADM level was not significantly.

\subsubsection{Joint swelling}

To evaluate the anti-inflammatory effect of ADM on arthritis, we used calipers to measure joint swelling in ADM-treated knees and compared the swelling with that at the same level on the contralateral knees, treated with saline. In rabbits with AIA treated with daily injections of ADM or saline into the knee joint spaces for 7 days, $3 \mu \mathrm{g}$ ADM significantly reduced joint swelling compared with contralateral knees after day 5. No significant decrease in joint swelling was observed, however, in knees treated with $<0.1 \mu \mathrm{g}$ ADM (Fig. $9 \mathrm{a}$ and 10$)$.
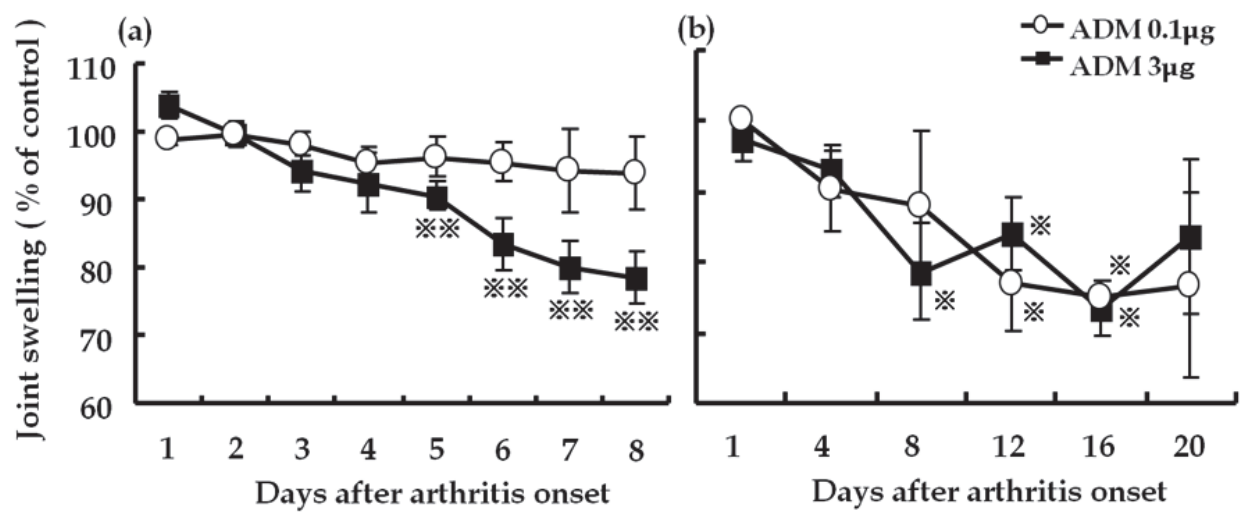

Fig. 9. Adrenomedullin reduced joint swelling in rabbits with antigen-induced arthritis.

(a) Joint swelling progress in rabbits with AIA treated with daily intra-articular injections of ADM or saline for 7 days ( $n=5$ in each group). Daily intra-articular injections of $3 \mu \mathrm{g}$ ADM significantly decreased joint swelling compared with contralateral knees after day 5 . No significant decrease in joint swelling was observed in knees treated with $<0.1 \mu \mathrm{g}$ ADM.

(b) Joint swelling progress in rabbits with AIA treated with daily intra-articular injections of ADM or saline for 20 days ( $n=3$ in each group). Daily intra-articular injections of $0.1 \mu \mathrm{g}$ and $3 \mu \mathrm{g}$ ADM showed a tendency to reduce joint swelling throughout the experiment, and significantly decreased joint swelling on days 12 and 16 and on days 8, 12 and 16, respectively, compared with contralateral control knees. Daily intra-articular injections of 1 ng and $0.01 \mu \mathrm{g}$ ADM did not ameliorate joint swelling throughout the experiments (data not shown). Data expressed as the mean \pm standard error of the mean. ${ }^{*} P<0.05$ and ${ }^{* *} P<0.01$, compared with contralateral knees.

In rabbits with AIA treated for 20 days with daily injections of ADM or saline into the knee joint spaces, $0.1 \mu \mathrm{g}$ and $3 \mu \mathrm{g}$ ADM showed a tendency to reduce joint swelling throughout the experiment - and significantly decreased joint swelling on days 12 and 16 and on days 8, 12 and 16, respectively, compared with contralateral knees (Fig. 9b). Daily intra-articular injections of $1 \mathrm{ng}$ and $0.01 \mu \mathrm{g}$ ADM, however, did not ameliorate joint swelling (data not shown). 

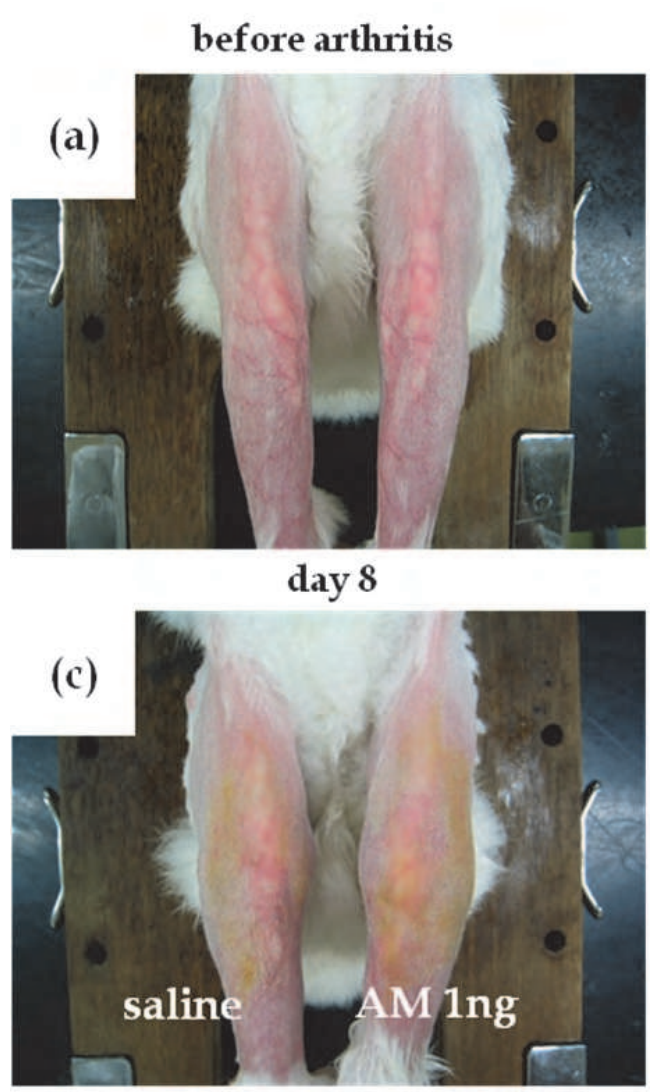
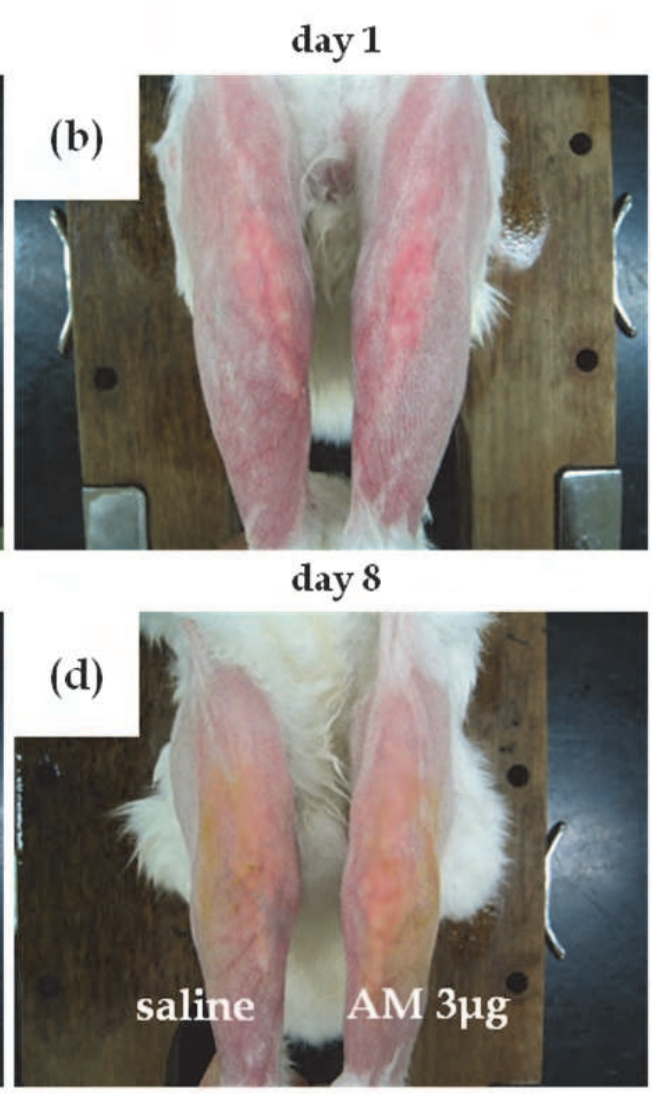

Fig. 10. Macroscopic pathology of joint swelling in rabbits with antigen-induced arthritis

(a) Photograph taken before arthritis onset. (b) Photograph taken 24 hours after arthritis onset. (c) The left knee of the rabbit with antigen-induced arthritis (AIA) was treated with daily intra-articular injections of $1 \mathrm{ng}$ ADM for 7 days and the right knee was treated with daily intra-articular injections of saline for 7 days. Photograph taken 8 days after arthritis onset. (d) The left knee of the rabbit with AIA was treated with daily intra-articular injections of $3 \mu \mathrm{g}$ ADM for 7 days and the right knee was treated with daily intra-articular injections of saline for 7 days. Photograph taken 8 days after arthritis onset.

\subsubsection{Histological findings}

The infrapatellar fat pads harvested from control knees on day 8 showed a dense inflammatory reaction, including edematous changes in the synovial interstitium, intracellular edema in the infrapatellar fat pads, hyperplasia of synovial surface cells and widespread infiltration of inflammatory cells in the infrapatellar fat pads (Fig. 11d,e,f). In contrast, these inflammatory reactions were suppressed in the knees treated with ADM for 7 days. In particular, edematous changes in the synovial interstitium, intracellular edema in the infrapatellar fat pads and infiltration of inflammatory cells in the deep 
portion of the infrapatellar fat pads were significantly reduced (Fig. 11a,b,c). The infrapatellar fat pads harvested from control knees on day 21 also showed a severe inflammatory reaction. Edematous changes in the synovial interstitium, hyperplasia of synovial surface cells and widespread infiltration of inflammatory cells throughout the infrapatellar fat pads were observed (Fig. 12d,e,f). In the knees treated with ADM for 20 days, these inflammatory reactions were ameliorated. ADM treatment significantly suppressed infiltration of inflammatory cells in the deep portion of the infrapatellar fat pads (Fig. 12a,b,c).

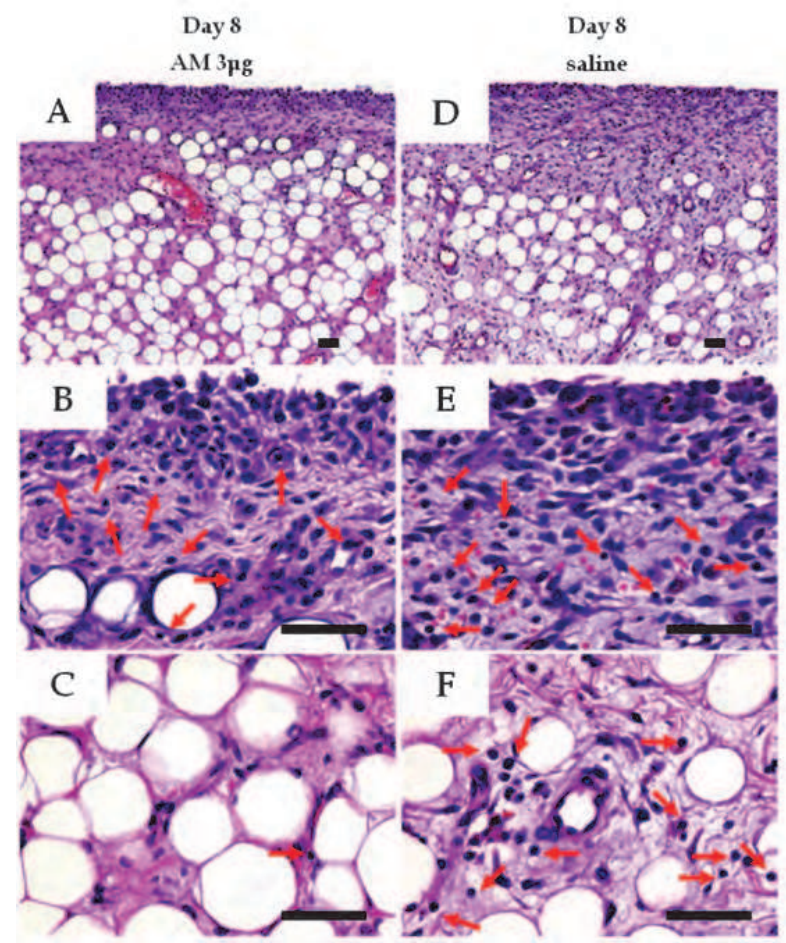

Fig. 11. Histological analysis of infrapatellar fat pad harvested from rabbit knees 8 days after arthritis onset

Rabbits with antigen-induced arthritis (AIA) were treated with daily injections of ADM or saline (control) into the knee joint spaces for 7 days. Tissues were sectioned longitudinally perpendicular to the patella ligament in the middle of the tissue, and were stained with $\mathrm{H}$ \& E. (a), (b), (c) AIA rabbit knee was treated with daily intra-articular injections of $3 \mu \mathrm{g}$ ADM for 7 days. (a) Low-magnification image $(\times 100)$. (b), (c) High-magnification images $(\times 400)$ of the superficial portion and the deep portion of (a), respectively. (d), (e), and (f) the contralateral knee of (a), (b) and (c) was treated with daily intra-articular injections of saline for 7 days. (d) Low-magnification image $(\times 100)$. (e), (f) High-magnification images $(\times 400)$ of the superficial portion and the deep portion of (d), respectively. Arrows indicate inflammatory cells. Bar $=50 \mu \mathrm{m}$. 


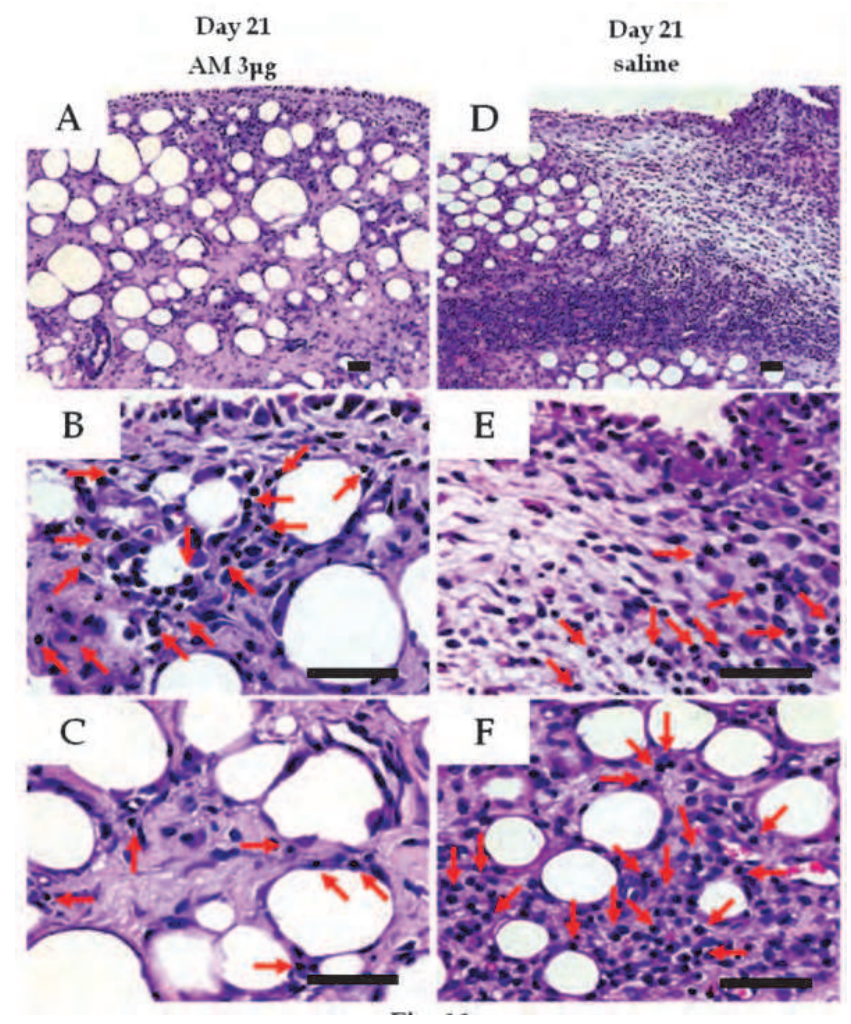

Fig. 12. Histological analysis of infrapatellar fat pad harvested from rabbit knees 21 days after arthritis onset

Rabbits with antigen-induced arthritis (AIA) were treated with daily injections of ADM or saline (control) into the knee joint spaces for 20 days. (a), (b), (c) AIA rabbit knee was treated with daily intra-articular injections of $3 \mu \mathrm{g}$ AM for 20 days. (a) Low-magnification image $(\times 100)$. (b), (c) High-magnification images $(\times 400)$ of the superficial portion and the deep portion of (a), respectively. (d), (e), and (f) the contralateral knee of (a), (b) and (c) was treated with daily intra-articular injections of saline for 20 days. (d) Lowmagnification image $(\times 100)$. (e), (f) High-magnification images $(\times 400)$ of the superficial portion and the deep portion of $(\mathrm{d})$, respectively. Arrows indicate inflammatory cells. Bar $=50 \mu \mathrm{m}$.

\subsubsection{Collagen volume in infrapatella fat pads treated with Adrenomedullin}

To observe the effect of ADM on fibrosis of the infrapatellar fat pads harvested on day 21, we examined the collagen volume ratio of the infrapatellar fat pad histologically using Mallory-Azan staining. The collagen volume ratio was significantly increased in ADMtreated knees by $39 \%$ and $31 \%$ at $0.1 \mu \mathrm{g}$ and $3 \mu \mathrm{g}$ ADM, respectively, compared with control knees (Fig. 13 and 14). The effects of ADM on these pathological tissue changes, however, were not observed in knees treated with low-dose ADM. 

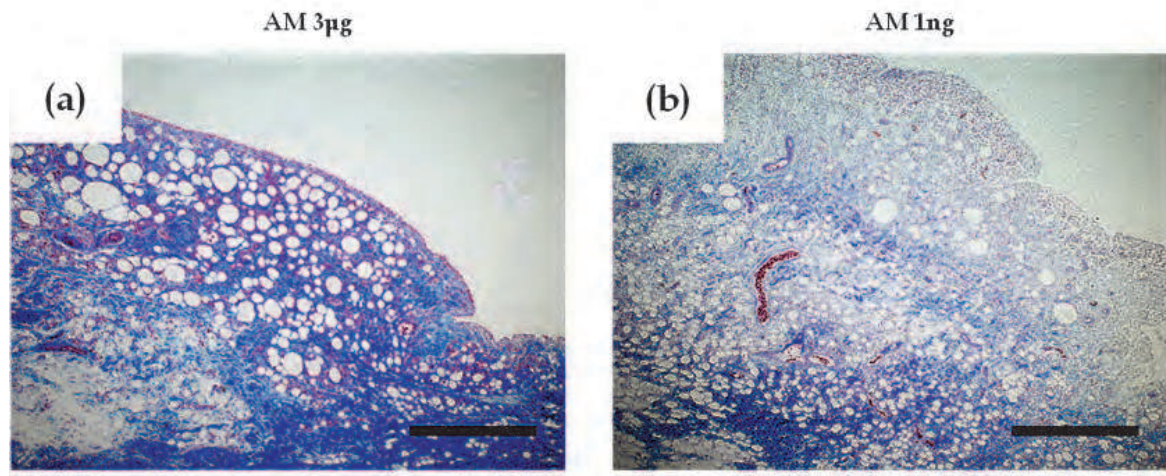

saline

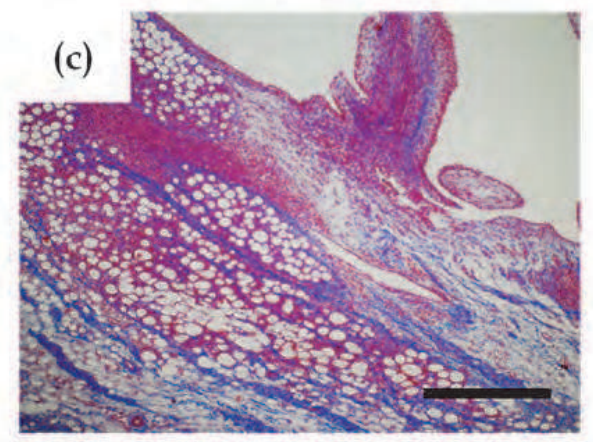

Fig. 13. Histological analysis of infrapatellar fat-pad sections stained with Mallory - Azan from rabbits with antigen-induced arthritis

The tissues were sectioned longitudinally perpendicular to the patella ligament in the middle of the tissue, and were stained with Mallory - Azan. (a) AIA rabbit knee was treated with daily intra-articular injections of $3 \mu \mathrm{g}$ ADM for 20 days. (b) AIA rabbit knee was treated with daily intra-articular injections of $1 \mathrm{ng}$ ADM for 20 days. (c) The contralateral knee of (a) was treated with daily intra-articular injections of saline for 20 days. Photographs taken at $\times 40$ magnification. Bar $=500 \mu \mathrm{m}$.

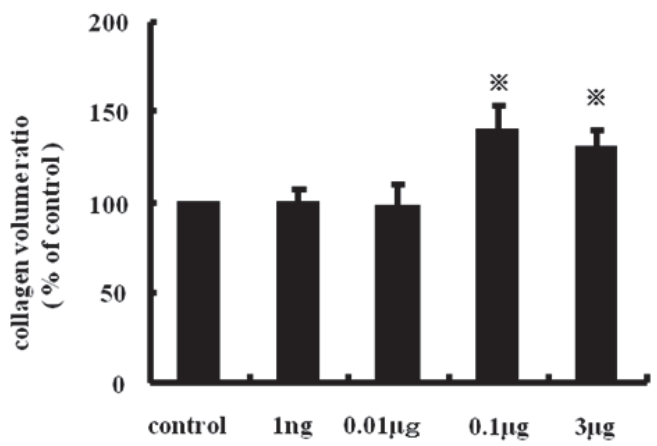

Fig. 14. Quantitative evaluation of collagen volume in the infrapatellar fat pad 
The collagen volume ratio was increased in ADM-treated knees by $39 \%$ and $31 \%$ at $0.1 \mu \mathrm{g}$ and $3 \mu \mathrm{g}$ ADM, respectively. Data expressed as the mean \pm standard error of the mean. ${ }^{*} P<$ 0.05 , compared with contralateral knees.

\subsubsection{Cytokines}

To elucidate the mechanism of the anti-inflammatory effects of AM in inflamed joints, we investigated the effect of AM on cytokine mRNA expression linked to AIA. Treatment with AM reduced TNFa mRNA expression in a dose-dependent manner. Daily intra-articular injections of $3 \mu \mathrm{g}$ AM significantly suppressed the TNFa mRNA level by $21 \%$ and $49 \%$ at day 8 and day 21, respectively, compared with controls (Fig. 15a). In contrast, AM dosedependently increased IL-6 mRNA expression. Daily intra-articular injections of $3 \mu \mathrm{g}$ AM significantly increased the IL- 6 mRNA level by $45 \%$ and $121 \%$ at day 8 and day 21, respectively, compared with controls (Fig. 15b). Although the VEGF mRNA level was suppressed by $10 \%$ at $3 \mu \mathrm{g}$ AM on day 8 , we did not observe a dose-dependent effect of AM on VEGF mRNA expression (Fig. 15d). AM treatment did not significantly alter the TGF $\beta$ mRNA level (Fig. 15c).

(a)

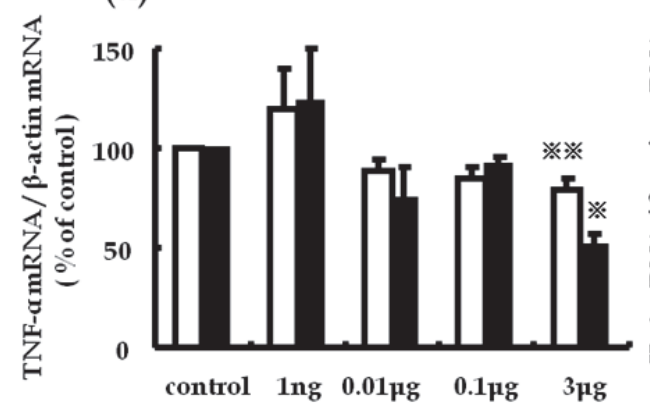

(c)

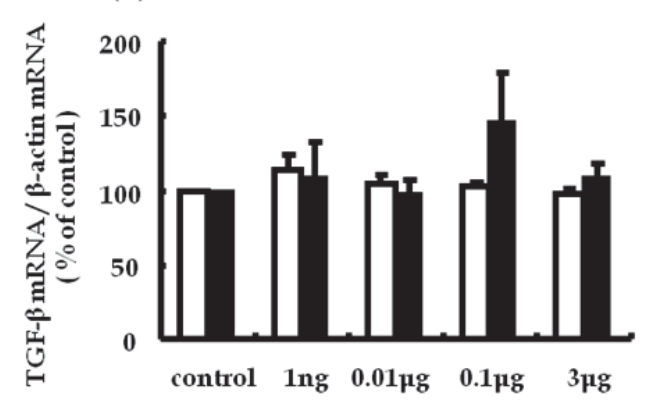

(b)
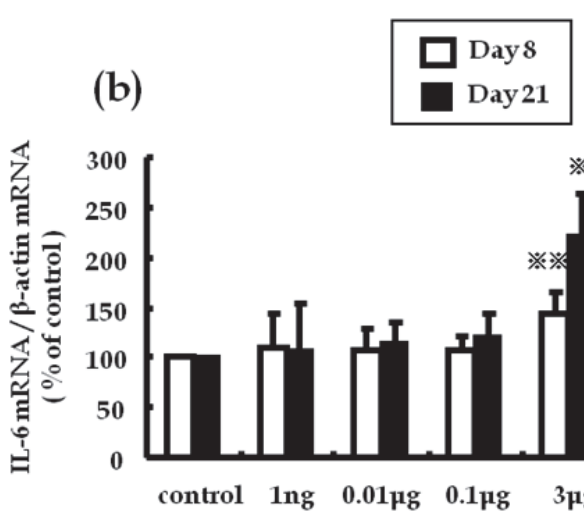

(d)

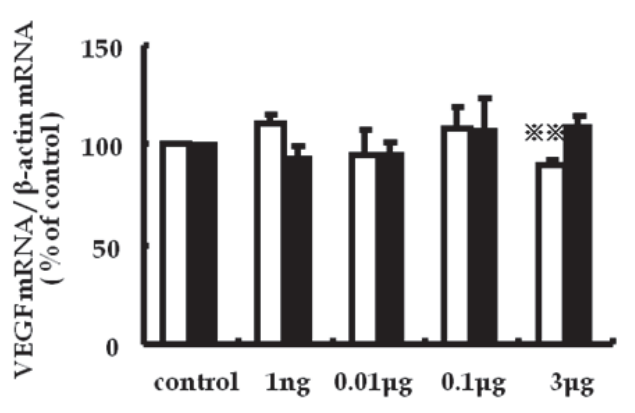

Fig. 15. Effect of adrenomedullin on cytokine mRNA expression linked to antigen-induced arthritis 
Expression levels of TNFa, IL-6, transforming growth factor beta (TGF $\beta$ ), and vascular endothelial growth factor (VEGF) mRNA in the infrapatellar fat pads were determined by real-time quantitative PCR. (a) ADM treatment reduced TNFa mRNA expression in a dosedependent manner. Daily intra-articular injections of $3 \mu \mathrm{g}$ ADM significantly suppressed the TNFa mRNA level by $21 \%$ and $49 \%$ at day 8 and day 21 , respectively. (b) ADM increased IL-6 mRNA expression in a dose-dependent manner. Daily intra-articular injections of $3 \mu \mathrm{g}$ AM significantly increased the IL- 6 mRNA level by $45 \%$ and $121 \%$ at day 8 and day 21 , respectively. (c) ADM treatment did not alter the TGF $\beta$ mRNA level. (d) Although the VEGF mRNA level was suppressed by $10 \%$ at $3 \mu \mathrm{g}$ AM on day 8 , a dose-dependent effect of ADM on VEGF mRNA expression was not observed. Open and closed columns represent the data at day 8 ( $n=5$ in each group) and day 21 ( $n=3$ in each group), respectively. Data expressed as the mean \pm SEM. ${ }^{*} P<0.05$ and ${ }^{* *} P<0.01$, compared with contralateral knees

\subsection{Therapeutic efficacy of ADM injection to the knee in AIA in rabbits}

In the present study we have shown that daily injections of ADM into the knee joint spaces of rabbits with AIA ameliorated the inflammatory response associated with the disease. Treatment with ADM reduced joint swelling, and reduced the expression of TNFa mRNA, edematous changes and the number of infiltrating inflammatory cells in the synovial tissue. We observed that ADM suppressed joint swelling (Fig. 9 and 10). Histologically, ADM treatment reduced edematous changes and increased the ratio of connective tissue in the infrapatellar fat pad (Fig. 13 and 14). A previous study showed that TNFa induced cytoskeletal reorganization of endothelial cells and increased endothelial permeability by stimulating TNF receptors 1 and 2 (Ferrero et al., 2001). In addition, TNFa facilitates the ability of VEGF to promote excessive vascular permeability (Clauss et al., 2001). TNFa also suppresses the expression of matrix genes and the induction of connective tissue growth factor by TGF $\beta$ during the wound healing response (Leask \& Abraham, 2004). TNFa therefore aggravates edematous changes and suppresses the fibrotic response of the tissue. Moreover, ADM was shown to reduce endothelial hyperpermeability induced by hydrogen peroxide, thrombin, and Escherichia coli hemolysin (Hippenstiel et al., 2002).

Two research groups reported recently that ADM signaling deficiency in mice resulted in midgestation death and massive edema. The cause of this edema was shown to be a result of fragility and hyperpermeability of blood vessels in one group and to be a failure of lymphatic vessel growth in the other (Ichikawa et al., 2008; Fritz et al., 2008). The evidence from these studies suggests that ADM plays an important role in preventing edema. From these observations, we speculate that ADM not only suppresses the production of TNFa, but also directly and indirectly inhibits edematous changes in the inflamed joint.

Although RA is a chronic and systemic inflammatory disorder of unknown etiology, TNFa has been shown to play a central role in the pathogenesis of RA (Moreland et al., 1997; Elliott et al., 1993; Arend et al., 1995). TNFa stimulates the proliferation of synovial cells and the production of matrix metalloproteinases by chondrocytes and synovial cells, and induces the release of other proinflammatory cytokines, leading to joint destruction (Arend et al., 1995; Nishimoto et al., 2000). We have shown that daily injections of ADM into the knee joint spaces of rabbits with AIA suppressed the expression of TNFa mRNA in the synovial tissue in a dose-dependent manner (Fig. 15a). It has been reported that ADM suppressed the secretion of TNFa from lipopolysaccharide-stimulated RAW 264.7 macrophages and NR8383 macrophages (Wong et al., 2005; Kubo et al., 1998; Wu et al., 2003). Because the major source of TNFa in inflamed synovial tissue of RA is due to 
macrophages (Chu et al., 1991) it is plausible that ADM suppresses the production of TNFa from activated macrophages in inflamed synovial tissue.

On the contrary, we found that ADM increased IL-6 mRNA expression in the synovial tissue (Fig.15b). Our results agree with previous findings on the effects of ADM on IL-6 production. ADM is reported to augment the production of IL-6 from NR8383 cells and Swiss 3T3 fibroblast cells stimulated with lipopolysaccharide or cytokines (Isumi et al., 1998). Several observations support the concept that IL-6 is an anti-inflammatory cytokine (Tilg et al., 1997). IL-6 has been shown to have a suppressive effect on TNFa and IL-1 $\beta$ production in peripheral blood mononuclear cells and exerts its anti-inflammatory effects in hepatitis by reducing the production of TNF (Schindler et al., 1990; Mizuhara et al., 1994). Our results therefore lead us to speculate that the mechanism involved in the antiinflammatory effects of ADM is related to suppression of TNFa in inflamed synovial tissue directly or through IL-6 production.

Overproduction of IL-6 has been observed and is known to cause unfavorable clinical symptoms in immune-inflammatory diseases such as RA. Overproduction of IL-6 induces the production of rheumatoid factors and increases antibody levels, the platelet count, Creactive protein levels, and serum amyloid A protein levels in RA (Nishimoto et al., 2000). Treatment with a humanized anti-IL-6 receptor antibody has also been shown to reduce RA disease activity (Nishimoto et al., 2004). The effect of ADM on IL-6 production might therefore be an undesirable adverse effect in RA therapy. Plasma ADM levels have been reported to increase with RA disease activity and in the acute or flare phase of myocardial infarction and sepsis (Chosa et al., 2003; Yudoh et al., 1999; Kobayashi et al., 1996; Hirata et al., 1996). Recent studies have shown that ADM administration in the acute phase reaction of several disease models produced significant protective effects in organs against inflammation and oxidative stress (Kawai et al., 2004; Nakamura et al., 2004; Yang et al., 2002). Miyashita and colleagues reported that ADM administration to prevent ischemic brain damage in mice less than 72 hours after the ischemic event showed significant therapeutic effects, whereas ADM administration more than 72 hours after stroke onset produced no significant therapeutic effects (Miyashita et al., 2006).

From these observations and our study findings, we speculate that the effects of ADM may be dependent on the tissue environment and the disease state; that is, the role and effects of ADM in inflammation may change during the inflammatory process. ADM acts as a strong anti-inflammatory agent in the acute or flare phase of inflammation, but in the chronic phase of inflammation ADM may act not only as an anti-inflammatory agent but also as a proinflammatory agent. It is therefore important to consider the time of administration, the route of administration and the dosage schedule of ADM in the treatment of RA.

\section{Conclusions}

In our study, plasma ADM level was found to be elevated in patients with RA and the origin of ADM was shown to be synovial tissue. ADM may exert anti-inflammatory effects because the cultured RA synoviocytes secrete ADM, have ADM receptors, and inhibit IL-6 production. Therefore, the effects of daily intra-articular injections of ADM into the knees of rabbits with AIA were examined. The results suggest that ADM suppresses the inflammatory response in inflamed joints by inhibiting the expression of TNFa mRNA and increasing IL-6 mRNA level. 
Although ADM may have anti-inflammatory properties, the effect of ADM on IL-6 production in inflamed synovial tissue might be an undesirable adverse effect in RA therapy. Further research is necessary to investigate the drug effects, the time of administration, and the dosage schedules of intra-articular injection of ADM in the treatment of RA.

\section{Acknowledgment}

The authors would like to thank Prof. Kazuo Kitamura for his helpful discussion, Prof. Yujiro Asada for the offer of sample in the immunohistochemical study, and Ms Mariko Tokashiki for technical support in measurement of the plasma AM concentration.

\section{References}

Arend WP \& Dayer JM. (1995) Inhibition of the production and effects of interleukin-1 and tumor necrosis factor alpha in rheumatoid arthritis. Arthritis Rheum. Vol. 38, pp. 151-160

Asada Y, Hara S, Marutsuka K, Kitamura K, Tsuji T, Sakata J, Sato Y, Kisanuki A, Eto T \& Sumiyoshi A. (1999) Novel distribution of adrenomedullin-immunoreactive cells in human tissues. Histochem Cell Biol, Vol. 112, pp. 185-191.

Clementi G, Caruso A, Cutuli VM, Prato A, Mangano NG, Amico-Roxas M. (1999) Antiinflammatory activity of adrenomedullin in the acetic acid peritonitis in rats. Life Sci Vol.65, pp. 203-8.

Chosa E, Hamada H, Kitamura K, Eto T \& Tajima N.(2003) Increased plasma and joint tissue adrenomedullin concentrations in patients with rheumatoid arthritis compared to those with osteoarthritis. J Rheumatol. Vol. 30, pp. 2553-2556.

Chu CQ, Field M, Feldmann M \& Maini RN. (1991) Localization of tumor necrosis factor alpha in synovial tissues and at the cartilage-pannus junction in patients with rheumatoid arthritis. Arthritis Rheum. Vol. 34, pp. 1125-1132.

Clauss M, Sunderkötter C, Sveinbjörnsson B, Hippenstiel S, Willuweit A, Marino M, Haas E, Seljelid R, Scheurich P, Suttorp N, Grell M \& Risau W. (2001)A permissive role for tumor necrosis factor in vascular endothelial growth factor-induced vascular permeability. Blood. Vol. 97, pp. 1321-29.

Clegg DO \& Ward JR. (1987) Diagnostic criteria in rheumatoid arthritis. Scand J Rheumatol Suppl. Vol. 65, pp. 3-11. Review

Consden R, Doble A, Glynn LE \& Nind AP. (1971) Production of a chronic arthritis with ovalbumin. Its retention in the rabbit knee joint. Ann Rheum Dis. Vol. 30, pp. 307315.

Elliott MJ, Maini RN, Feldmann M, Long-Fox A, Charles P, Katsikis P, Brennan FM, Walker J, Bijl H, Ghrayeb J, et al. (1993) Treatment of rheumatoid arthritis with chimeric monoclonal antibodies to tumor necrosis factor alpha. Arthritis Rheum. Vol. 36, pp. 1681-1690.

Elsasser TH \& Kahl S. (2002) Adrenomedullin has multiple roles in disease stress: development and remission of the inflammatory response. Microsc Res Tech Apr 15 Vol. 57. pp. 120-9. 
Ferrero E, Zocchi MR, Magni E, Panzeri MC, Curnis F, Rugarli C, Ferrero ME \& Corti A. (2001) Roles of tumor necrosis factor p55 and p75 receptors in TNF-a-induced vascular permeability. Am J Physiol Cell Physiol. Oct. Vol. 281, pp. c1173-c1179.

Fritz-Six KL, Dunworth WP, Li M \& Caron KM. (2008) Adrenomedullin signaling is necessary for murine lymphatic vascular development. J Clin Invest. Vol. 118, pp. 40-50.

Hamada H, Saisyo K, Sekimoto T, Chosa E. (2010) Plasma adrenomedullin and proadrenomedullin $\mathrm{N}$-terminal 20 peptide in patients diagnosed as having early rheumatoid arthritis. Mod Rheumatol. Aug. Vol. 20(4), pp. 89-95.

Hip.penstiel S, et al. (2002) Adrenomedullin reduces endothelial hyperpermeability. Circ Res.(91):618-625.

Hofbauer KH, Schoof E, Kurtz A \& Sandner P. (2002) Inflammatory cytokines stimulate adrenomedullin expression through nitric oxide-dependent and -independent pathways. Hypertension, Vol. 39, pp. 161-7.

Hirata Y, Mitaka C, Sato K, Nagura T, Tsunoda Y, Amaha K, Marumo F. (1996) Increased circulating adrenomedullin, a novel vasodilatory peptide, in sepsis. J Clin Endocrinol Metab. Vol. 81, pp. 1449-1453.

Hojo Y, Ikeda U, Ohya K, Ichida M, Kario K, Takahashi M, Ikeda M, Minota S, Isumi Y, Minamino N, Ishimitsu T \& Shimada K. (2001, Apr) Interaction between monocytes and vascular endothelial cells induces adrenomedullin production. Atherosclerosis. Vol. 155 (2), pp. 381-7.

Ichikawa-Shindo Y, Sakurai T, Kamiyoshi A, Kawate H, Iinuma N, Yoshizawa T, Koyama T, Fukuchi J, Iimuro S, Moriyama N, Kawakami H, Murata T, Kangawa K, Nagai R \& Shindo T. (2008) The GPCR modulator protein RAMP2 is essential for angiogenesis and vascular integrity. J Clin Invest. Vol. 118, pp.29-39.

Ishimitsu T, Nishikimi T, Saito Y, Kitamura K, Eto T, Kangawa K, Matsuo H, Omae T \& Matsuoka H. ( 1994) Plasma levels of adrenomedullin, a newly identified hypotensive peptide, in patients with hypertension and renal failure. J Clin Invest. Vol. 94, pp. 2158-61.

Isumi Y, Minamino N, Kubo A, Nishimoto N, Yoshizaki K, Yoshioka M, Kangawa K \& Matsuo H. (1998) Adrenomedullin stimulates interleukin-6 production in Swiss 3T3 cells. Biochem Biophys Res Commun. Vol. 244, pp. 325-331.

Isumi Y, Kubo A, Katafuchi T, Kangawa K \& Minamino N. (1999) Adrenomedullin suppresses interleukin-1 beta-induced tumor necrosis factor-alpha production in Swiss 3 T3 cells. FEBS Lett Vol. 463, pp. 110-4.

Kamoi H, Kanazawa H, Hirata K, Kurihara N, Yano Y \& Otani S. (1995) Adrenomedullin inhibits the secretion of cytokine-induced neutrophil chemoattractant, a member of the interleukin-8 family,from rat alveolar macrophages. Biochem Biophys Res Commun Vol. 21, pp. 1031-5.

Kawai J, Ando K, Tojo A, Shimosawa T, Takahashi K, Onozato ML, Yamasaki M, Ogita T, Nakaoka T \& Fujita T. (2004) Endogenous adrenomedullin protects against vascular response to injury in mice. Circulation, vol. 109, pp. 1147-1153. 
Nanki T, Nagasaka K, Hayashida K, Saita Y and Miyasaka N.(2001) Chemokines regulate IL-6 and IL-8 production by fibroblast-like synoviocytes from patients with rheumatoid arthritis J Immunol. Nov 1; Vol. 167(9):5381-5

Kellgren JH \& Lawrence JL. (1958) Osteoarthritis and disc degeneration in an urban population. Ann Rheum Dis. Vol. 17, pp. 388-97.

Kitamura K, Kangawa K, Kawamoto M, Ichiki Y, Nakamura S,Matsuo H \& Eto T (1993) Adrenomedullin: a novel hypotensive peptide isolated from human pheochromocytoma. Biochem Biophys Res Commun Vol. 192, pp. 553-560

Kitamura K, Ichiki Y, Tanaka M, Kawamoto M, Emura J, Sakakibara S, Kangawa K, Matsuo H \& Eto T. (1994) Immunoreactive adrenomedullin in human plasma. FEBS Lett Vol. 341, pp. 288-90.

Kita T, Kitamura K, Hashida S, Morishita K \& Eto T. (2003) Plasma adrenomedullin is closely correlated with pulse wave velocity in middle-aged and elderly patients. Hypertens Res. Vol. 26, pp. 887-893

Kobayashi K, Kitamura K, Hirayama N, Date H, Kashiwagi T, Ikushima I, Hanada Y, Nagatomo Y, Takenaga M, Ishikawa T, Imamura T, Koiwaya Y \& Eto T. (1996) Increased plasma adrenomedullin in acute myocardial infarction. Am Heart J. Vol. 131, pp. 676-680.

Kubo A, Minamino N, Isumi Y, Katafuchi T, Kangawa K, Dohi K \& Matsuo H. ( 1998) Production of adrenomedullin in macrophage cell line and peritoneal macrophage. J Biol Chem. Vol. 273, pp. 16730-16738.

Leask A \& Abraham DJ. (2004) TGF- $\beta$ signaling and the fibrotic response. FASEB J Vol. 18, pp. 816-827.

Miyashita K, Itoh H, Arai H, Suganami T, Sawada N, Fukunaga Y, Sone M, Yamahara K, Yurugi-Kobayashi T, Park K, Oyamada N, Sawada N, Taura D, Tsujimoto H, Chao TH, Tamura N, Mukoyama M \& Nakao K. (2006) The neuroprotective and vasculoneuro-regenerative roles of adrenomedullin in ischemic brain and its therapeutic potential. Endocrinology. Vol.147, pp. 1642-1653.

Mizuhara H, O'Neill E, Seki N, Ogawa T, Kusunoki C, Otsuka K, Satoh S, Niwa M, Senoh H \& Fujiwara H. (1994) T cell activation-associated hepatic injury: mediation by tumor necrosis factors and protection by interleukin 6. J Exp Med. Vol.179, pp. 1529-1537.

Moreland LW, Baumgartner SW, Schiff MH, Tindall EA, Fleischmann RM, Weaver AL, Ettlinger RE, Cohen S, Koopman WJ, Mohler K, Widmer MB \& Blosch CM. (1997) Treatment of rheumatoid arthritis with a recombinant human tumor necrosis factor receptor (p75)-Fc fusion protein. N Engl J Med. Vol. 337, pp. 141-147.

Nakamura R, Kato J, Kitamura K, Onitsuka H, Imamura T, Cao Y, Marutsuka K, Asada Y, Kangawa K \& Eto T. (2004) Adrenomedullin administration immediately after myocardial infarction ameliorates progression of heart failure in rats. Circulation. Vol. 110, pp. 426-431.

Nishikimi T, Saito Y, Kitamura K, Ishimitsu T, Eto T, Kangawa K, Matsuo H, Omae T \& Matsuoka H. (1995) Increased plasma levels of adrenomedullin in patients with heart failure. J Am Coll Cardiol. Vol. 26, pp. 1424-31. 
Nishimoto N, Ito A, Ono M, Tagoh H, Matsumoto T, Tomita T, Ochi T \& Yoshizaki K. (2000) IL-6 inhibits the proliferation of fibroblastic synovial cells from rheumatoid arthritis patients in the presence of soluble IL-6 receptor. Int Immunol. Vol. 12, pp. 187-193.

Nanke Y, Kotake S, Yonemoto K, Saito S, Tomatsu T, Kamatani N. (2003) Adrenomedullin in synovial fluids from patients with rheumatoid arthritis inhibits interleukin 6 production from synoviocytes. Ann Rheum Dis. Jan, Vol. 62(1), pp. 82-3.

Nishimoto N, Kishimoto T \& Yoshizaki K. (2000) Anti-interleukin 6 receptor antibody treatment in rheumatic disease. Ann Rheum Dis. Vol. 59 (Suppl 1), pp. i21-i27.

Nishimoto N, Yoshizaki K, Miyasaka N, Yamamoto K, Kawai S, Takeuchi T, Hashimoto J, Azuma J \& Kishimoto T. (2004) Treatment of rheumatoid arthritis with humanized anti-interleukin-6 receptor antibody: a multicenter, double-blind, placebocontrolled trial. Arthritis Rheum. Vol. 50, pp. 1761-1769.

Okura T, Marutsuka K, Hamada H, Sekimoto T, Fukushima T, Asada Y, Kitamura K, Chosa E. (2008) Therapeutic efficacy of intra-articular adrenomedullin injection in antigen-induced arthritis in rabbits. Arthritis Res Ther. Vol. 10(6), pp133. Epub

Schindler R, Mancilla J, Endres S, Ghorbani R, Clark SC, Dinarello CA. (1990) Correlations and interactions in the production of interleukin-6 (IL-6), IL-1, and tumor necrosis factor (TNF) in human blood mononuclear cells: IL-6 suppresses IL-1 and TNF. Blood. Vol. 75, pp. 40-47.

Tilg H, Dinarello CA \& Mier JW. (1997) IL-6 and APPs: anti-inflammatory and immunosuppressive mediators. Immunol Today. Vol. 18, pp. 428-432.

Ueda S, Nishio K, Minamino N, Kubo A, Akai Y, Kangawa K, Matsuo H, Fujimura Y, Yoshioka A, Masui K, Doi N, Murao Y \& Miyamoto S. (1999) Increased plasma levels of adrenomedullin in patients with systemic inflammatory response syndrome. Am J Respir Crit Care Med Vol. 160, pp. 132-6.

Uemura T, Kato J, Kuwasako K, Kitamura K, Kangawa K \& Eto T. (2002) Aldosterone augments adrenomedullin production without stimulating pro-adrenomedullin $\mathrm{N}$ terminal 20 peptide secretion in vascular smooth muscle cells. J. Hypertension Vol. 20 (6), pp. 1209-14

Wong LY, Cheung BM, Li YY \& Tang F. (2005) Adrenomedullin is both proinflammatory and antiinflammatory: its effects on gene expression and secretion of cytokines and macrophage migration inhibitory factor in NR8383 macrophage cell line. Endocrinology. Vol. 146, pp. 1321-1327.

Wu R, Zhou M \& Wang P. (2003) Adrenomedullin and adrenomedullin binding protein-1 downregulate TNF-a in macrophage cell line and rat Kupffer cells. Regul Pept. Vol. 112, pp. 19-26.

Yang S, Zhou M, Fowler DE \& Wang P. (2002) Mechanisms of the beneficial effect of adrenomedullin and adrenomedullin-binding protein-1 in sepsis: downregulation of proinflammatory cytokines. Crit Care Med. Vol. 30, pp. 27292735 . 
Yudoh K, Matsuno H \& Kimura T. (1999) Plasma adrenomedullin in rheumatoid arthritis compared with other rheumatic diseases. Arthritis Rheum, Vol. 42, pp. 1297-8.

Zagariya A, Bhat R, Navale S, Chari G \& Vidyasagar D. (2006) Inhibition of meconiuminduced cytokine expression and cell apoptosis by pretreatment with captopril. Pediatrics. Vol. 117, pp. 1722-1727 


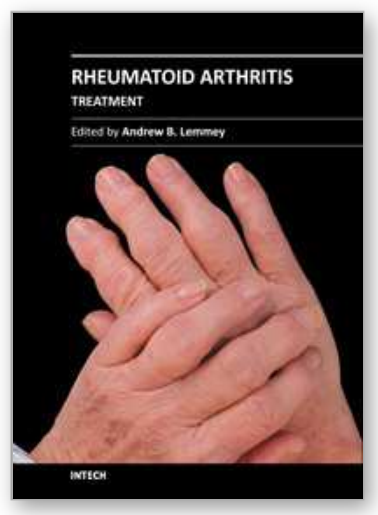

\author{
Rheumatoid Arthritis - Treatment \\ Edited by Dr. Andrew Lemmey
}

ISBN 978-953-307-850-2

Hard cover, 366 pages

Publisher InTech

Published online 18, January, 2012

Published in print edition January, 2012

The purpose of this book is to provide up-to-date, interesting, and thought-provoking perspectives on various aspects of research into current and potential treatments for rheumatoid arthritis (RA). This book features 17 chapters, with contributions from numerous countries (e.g. UK, USA, Canada, Japan, Sweden, Turkey, Bosnia and Herzegovina, Slovakia), including chapters from internationally recognized leaders in rheumatology research. It is anticipated that Rheumatoid Arthritis - Treatment will provide both a useful reference and source of potential areas of investigation for research scientists working in the field of RA and other inflammatory arthropathies.

\title{
How to reference
}

In order to correctly reference this scholarly work, feel free to copy and paste the following:

Etsuo Chosa, Hiroaki Hamada and Toshiyuki Ohkura (2012). Role of Adrenomedullin in Patients with Rheumatoid Arthritis, Rheumatoid Arthritis - Treatment, Dr. Andrew Lemmey (Ed.), ISBN: 978-953-307-850-2, InTech, Available from: http://www.intechopen.com/books/rheumatoid-arthritis-treatment/role-ofadrenomedullin-in-patients-with-rheumatoid-arthritis

\section{INTECH}

open science | open minds

\section{InTech Europe}

University Campus STeP Ri

Slavka Krautzeka 83/A

51000 Rijeka, Croatia

Phone: +385 (51) 770447

Fax: +385 (51) 686166

www.intechopen.com

\section{InTech China}

Unit 405, Office Block, Hotel Equatorial Shanghai

No.65, Yan An Road (West), Shanghai, 200040, China

中国上海市延安西路65号上海国际贵都大饭店办公楼405单元

Phone: +86-21-62489820

Fax: +86-21-62489821 
(C) 2012 The Author(s). Licensee IntechOpen. This is an open access article distributed under the terms of the Creative Commons Attribution 3.0 License, which permits unrestricted use, distribution, and reproduction in any medium, provided the original work is properly cited. 